\title{
Buddhism and Silk: Reassessing a Painted Banner from Medieval Central Asia in the Metropolitan Museum of Art
}

\section{Introduction}

Among the silk route artifacts in The Metropolitan Museum of Art is a painted silk banner that depicts a Buddhist deity standing beneath a canopy (Figure 1). The relatively small size of this banner belies its significance as an artifact attesting to transcultural exchange between the silk road oasis city of Dunhuang and neighboring kingdoms of the premodern silk routes in Central Asia. Furthermore, the materiality and iconography of the banner demonstrate the intertwined resonance of Buddhism and silk and offer tantalizing insights into cross-cultural practices of artistic production and display.

Aided by conservation work recently undertaken in the museum's Department of Textile Conservation, the authors examine the painted banner from interdisciplinary perspectives. Firstly, the banner is placed in its religious and cultural context through comparisons made to comparable painted silk banners recovered from Dunhuang, located in present-day Gansu Province in northwestern China. Secondly, a close examination of a hitherto unrecognized inscription points to the close ties that were cultivated between Dunhuang and Khotan, a neighboring kingdom that played a critical role in the transmission of Buddhism. The last part of the article reconstructs the probable route taken by the banner from Dunhuang to early twentieth century London, and of the roles played by the archaeologist Marc Aurel Stein and his assistant Frederick Henry Andrews. In doing so, the continued transcultural significance of the banner into the present-day is foregrounded.

\section{The Great Peacock Wisdom King}


The central motif of this banner is a deity standing atop a lotus pedestal, exquisitely bejeweled and sumptuously attired in colorful textiles. A flowered canopy overhead is adorned with tassels that fall behind the deity's arched halo. The floral motif of the canopy is echoed by small blossoms that fall from the sky and appear as if suspended in mid-air, lending their appealing fragrance to the scene. The deity bears implements of religious significance in both hands: a single peacock feather in the right hand and a golden bowl in the left hand.

Together, the peacock feather and golden bowl identify the deity as Mahāmayūrī, the Great Peacock Wisdom King. In the East Asian Buddhist canon, Mahāmayūrī is known from six translations of the Sütra of the Great Golden Peacock King Mantra that were made between the fourth to eighth centuries. ${ }^{1}$ Several of these were completed by monk-translators from oasis kingdoms of the Tarim Basin, indicating the popularity of this deity along the silk routes. ${ }^{2} \mathrm{~A}$ mantra or dhāraṇī (the two terms were often used interchangeably) refers to a verbal incantation that was recited orally in order to harness the titular deity's efficacious powers.

In the framing narrative of the sūtra, the protagonist is a young monk named Svāti, who resides in the Jetavana Grove. One day, he is bitten on the right foot by a poisonous black snake while gathering firewood for the monks' bath. ${ }^{3}$ Witnessing his pain and suffering, the Buddha's disciple Ānanda pleads with the Buddha for help. ${ }^{4}$ The Buddha tells Ananda that he should recite the Mahāmāyūrī dhāraṇī sūtra, which has the power to save the young monk by neutralizing the snake's poison. ${ }^{5}$ For this reason, Mahāmayūrī was particularly known for protection against snake bites and associated with medicine. This is conveyed by the golden bowl held by the deity, which represents a bowl of medicine. ${ }^{6}$ The medical properties of the Mahāmayūrī dhāraṇī likely resulted in its incorporation into the Bower Manuscript, dating to the Gupta Period in India (ca. 320-550), which was recovered in 1890 by Col. Hamilton Bower in the underground crypt of a 
stupa (Buddhist reliquary mound) located in Kumtura. ${ }^{7}$ Composed in Sanskrit and written in the Brāhmī script on birch bark, the Bower Manuscript contained several additional Indian medical treatises.

The peacock feather held by Mahāmayūrī refers to the deity's elevated status and the creature with which it is closely associated. According to textual sources associated with Mahāmayūrī, the deity holds peacock feathers in one of its hands and if in a seated position, a golden peacock king is its vehicle. ${ }^{8}$ This relates to another framing narrative of the Mahāmāyūrī dhāraṇī sūtra, which concerns a golden peacock king (e.g., a bird) who recites the Mahāmayūrī dhāraṇi sūtra daily for self-protection: once in the morning and again at dusk. ${ }^{9}$

From the examples above, it can be seen that Mahāmāyūrī was closely associated with healing and with protection, both of which were properties common to dhāraṇīs or mantras. ${ }^{10}$ In medieval China, dhāraṇīs and mantras were not only recited, as prescribed by the Mahāmayūrī dhāraṇi sūtra, but they were also copied and worn on the body as talismans so that their efficacy could be transferred via direct contact with the devotee. ${ }^{11}$ Painted banners which were placed on public display, however, had very different material properties from smaller talismans.

Therefore, it is to the materiality of painted banners that we next turn.

\section{Materiality of Silk Road Banners}

Silk road banners are distinct from the more familiar hanging scrolls of East Asia. Unlike the conventional hanging scroll, painted banners were originally composed of multiple parts (Figure 2): the triangular banner head, which consisted of decorative silk or a painting, typically of a seated Buddha; the rectangular body on which the painting was executed (this could also consist of one or multiple pieces of fabric stitched together); side streamers attached to the wide border of the banner head; and bottom streamers attached to a wooden weighting board. A loop 
at the top of the banner head enabled the banner to be hung from poles or suspended from temple beams or stūpas (Figure 3).

The present banner is preserved in two pieces: the rectangular painting bearing the Mahāmāyūrī motif (Figure 1) and the triangular banner head painted with an image of a seated Buddha (Figure 4). The two are no longer attached (Figure 5), and also missing are the border of the banner head and the streamers. Nevertheless, the similarity in style, painting technique, and color palette between the present painting and the banner head suggest that they may have originated from the same object.

Silk road painted banners were made from a variety of materials, although the vast majority of those from Dunhuang were made on a silk support. In the early twentieth century, Marc Aurel Stein collected 230 banners from the Mogao caves at Dunhuang, of which 179 were made of silk, 42 from hemp, and 9 from paper. ${ }^{12}$ The lightweight and translucent quality of plain silk, in turn, was directly connected to the production of painted banners and their display. As previously mentioned, the efficacy of dhāraṇis and mantras was marshalled not only through oral recitation but also by the wearing of talismans bearing the syllables of a dhāranī or mantra. Yet other ways in which the efficacy of dhāranīs and mantras was transmitted was via the non-human agency of shadows and wind. ${ }^{13}$ In medieval China, dhāraṇis and mantras were often carved on the sides of stone pillars. It was believed that the shadows cast by a pillar or the dust lifted from its surface by wind had the capability to transfer the dhāraṇīs benefits onto devotees. ${ }^{14}$

There was a productive conflation in Buddhist texts concerning the lexicon of stone pillars and banners. Both were known in Chinese by the same word, chuang. ${ }^{15}$ It is therefore intriguing that dhāraṇī pillars and painted banners were similarly constructed according to a tripartite structure of head, body, and base (or bottom streamers). But whereas stone pillars were 
static, silk banners, by the lightweight and flexible nature of the material, were able to sway in the wind (Figure 6). This implies that unless hung directly against a wall or pillar, banners could be viewed from both sides.

Dunhuang manuscripts contain references to the visual impact of vibrantly colored silk banners swaying in the wind. For example, a passage in P.2044 describes the "skillful division of colors in woven silk and artful stitches in vermilion; hanging from a tall pole against the clear blue sky, the end of a rainbow flutters and appears in the sky; the wind [blows] it distantly one revolution and in one hundred places, disasters dissipate; its shadow appears to one thousand households and ten thousand kinds of fortune accumulate..."16

In spring 2019, the painted banner analyzed in this essay underwent detailed conservation work by Minsun Hwang and her team in the Department of Textile Conservation. At the time that the banner was acquired by the museum in 2007, it had been mounted onto a textile-covered panel, allowing only one side to be seen. The banner was removed from the panel (Figure 7), revealing that the front and back sides of the painting were both painted with the same motif of Mahāmayūrī, albeit with minor variations. In addition, the verso of the painting bore an inscription written in black ink that was faintly visible on the recto.

Extant double-sided banners from the silk routes were made from hemp, ramie, or silk, but the double-sided imagery was produced in different ways. Because hemp and ramie offer a more opaque painting ground than silk, the images on the front and back sides had to be drawn or transferred separately, either freehand or through the use of stencils. Paintings from the Turfan collection of the former Museum für Indische Kunst in Berlin show variations of doublesided painting. In some paintings, the same image was painted on both sides of a banner. Another ramie banner displays different though related motifs on each side: Dhṛtarāṣṭra and 
Virūpākșa, the guardian kings of the east and west, respectively (Figure 8a-b). They are identified by their attributes of a bow and arrow (Dhṛtarāșțra) and a flaming jewel (Virūpākșa). ${ }^{17}$

The translucent quality of silk, in contrast, enabled underpaintings that were made on one side to be visible from the other side. In the case of the Mahāmayūrī banner, black underpainting is seen on only one side, therefore designated as the recto (Figure 1); this effect is most visible in areas of bare skin and particularly in the deity's arms and upturned hand (Figure 9). ${ }^{18}$ The contours of the underpainting were carefully filled in with colored pigments, after which a deep red outline was painted over the black underpainting, partially obscuring it. The other side of the painting bears no traces of black underpainting, only red outlines, demonstrating that the silk was sufficiently sheer so as to render the black outlines visible on the verso. The same painting process followed in which colored pigments were applied, to be followed with the tracing of red outlines. The inscription referred to earlier was written on the verso. With the exception of minor motifs such as the rendering of flowers and the treatment of drapery around the deity's waist, the two paintings of Mahāmayūrī are mirror images of one another.

Another noteworthy element is the unusual attention paid to textiles in this painting. The deity is clad in an Indian-style skirt-like garment called a dhoti, which is comprised of a pale orange textile decorated with a regular pattern of blue and red quatrefoil-shaped flowers. This resembles clamp resist-dyed silk textiles recovered from oasis cities of the silk road. The clampresist dying technique resulted in symmetrical patterns of the sort seen in the dhoti worn by Mahāmayūrī. Wooden blocks carved with symmetrical patterns created through a juxtaposition of convex and concave shapes were affixed on either side of a piece of cloth or folded piece of cloth and clamped together, after which the cloth was placed in dye. The convex areas resisted dye while the concave areas created space for the dye to soak through the cloth. Multicolored 
patterns could be created through a combination of repeated clamp-resist dying and hand painting by brush. ${ }^{19}$

The garment is fastened around the waist with green, red, and purple cloth, and a doublefaced blue and red scarf billows artfully along the length of the deity's body. ${ }^{20}$ As important silk road commodities, the representation of silk textiles in this painted banner merits attention. The detailed representation of textiles in this banner is also evident in a separate group of painted banners that attests to the vibrancy of banner painting traditions along the southern silk route, and in particular, the artistic impact of the Buddhist kingdom of Khotan (Figure 10).

\section{Silk Banners on the Silk Road}

Of the silk banners recovered by Stein from Mogao Cave 17, a group of ten that were gathered during his second expedition serve as a particularly instructive point of comparison for the Mahāmayūrī banner. They are now divided between the British Museum (three paintings) and the National Museum of India in New Delhi (seven paintings). ${ }^{21}$ The works display stylistic traits of Khotanese and Himalayan artistic traditions, the latter of which reflects on the period of the Tibetan occupation of Khotan between the seventh-ninth centuries. Like the Mahāmayūrī banner, one of this group was inscribed on the verso. The Tibetan inscription identifies the deity represented on the recto as Vajrapāni (Figure 11). ${ }^{22}$ The writing of inscriptions on the verso rather than on the recto is more commonly seen among Himalayan thangkas, which are usually painted on a heavier canvas ground. The Mahāmayūrī banner and the ten banners from the British Museum and National Museum of India do not have cartouches, further distinguishing them from banners that were inscribed in Chinese.

The paintings reveal a number of consistencies, despite subtle variations in the color and

quality of the silk ground. ${ }^{23}$ Similar to the Mahāmayūrī banner, they feature a single bodhisattva 
standing under a round canopy in contrapposto atop a lotus pedestal, wearing a dhoti and scarves, holding a ritual implement, and adorned with gold jewelry and peaked crowns. The use of bright colors and the lavish attention paid to the linear, ikat-like patterned effects of the textiles are particularly striking. ${ }^{24}$

Does the Mahāmayūrī banner belong to this group? It shares the motif of a standing deity on a lotus pedestal, and the borders have similarly been sewn rather than painted. However, there are important differences. Although roughly the same height, the Mahāmayūrī banner is nearly twice as wide as the ten in New Delhi and London. The painting style also displays a greater sense of refinement, and the floral textile pattern is distinct from the striped ikat textiles of the other banners. Nevertheless, the Khotanese stylistic elements of the Mahāmayūrī banner are corroborated by visual and epigraphic evidence stemming from the painting itself.

Several features in the painting suggest that it was made in Khotan, or in Dunhuang by a Khotanese artist or one familiar with Khotanese stylistic idioms. A mural painting fragment purportedly from Khotan shows a peacock feather wielded in the hand of a deity (Figure 12). The three-dimensional modeling in the face and body of the deity and in the petals of the lotus pedestal are characteristic of the Khotanese painting style, as are the broad facial features, high arched eyebrows, heavily lidded eyes, and long nose bridge of Mahāmayūrī and the seated Buddha in the banner head (Figure 5). ${ }^{25}$ The painting further displays visual evidence of the cross-cultural exchanges that typically characterize Khotanese painting. ${ }^{26}$ The dramatically billowing ribbons attached to either side of the crown, for example, originate from those worn by Sasanian kings (Figure 13), demonstrating the afterlife of earlier Iranian motifs.

Due to the lightweight nature of painted banners and thus their portability, they provide an exciting glimpse into how Central Asian iconography and painting styles were transmitted 
along the silk routes. Importantly, as our knowledge of Khotanese painting is largely informed by mural painting fragments and paintings executed on wooden panels, the Mahāmayūrī banner provides valuable insight into Khotanese visual culture and Buddhist practice. The association of the Mahāmayūrī banner with a Khotanese donor is demonstrated, as follows, by a close reading of the painting's hitherto unexamined inscription.

\section{A Khotanese Official's Donation}

Transcription: yaraiṣä nāmai āmācä haiṣte tcahauryāṃ parṣāṃ ba’ysuśte brrī[ye ...

Translation: The āmāca-official named Yaraișa donated, in love of bodhi of the Four Assemblies, ...

The inscription on the Mahāmayūrī banner was written on the left edge of the verso side of the painting (Figure 14) in Khotanese, a middle Iranian language, and in the Brāhmī script. After the painting was completed, the writer must have turned the painting sideways and inscribed the text from left to right. ${ }^{27}$ The text begins right below the canopy above the image of Mahāmayūrī. The first syllable is unclear, but there is space for only one syllable in front of the second and third syllables, which are clearly rai and șä. The first syllable may be tentatively read as a $y a$. Thus, the first three syllables, which constitute the name of the donor, may be reconstructed as * Yaraișa. ${ }^{28}$ Due to damage, it is impossible to know how much text is missing at the end of the inscription. The last partially visible syllable is that of brrī, no doubt the beginning of the word brrīya- "love." The space of the torn section of the banner would have allowed for several more words. One would assume, on the basis of other similar inscriptions, that the intentions of the donor might have been expressed. The missing part might have also included the date when the painting was made, but this scenario is less likely because the date is usually given at the beginning of a dedicatory inscription. ${ }^{29}$ 
The meaning of the extant part of the inscription is otherwise clear: an official with the title of $\bar{a} m \bar{a} c a$, possibly named Yaraișa, donated something "in love of bodhi of the Four Assemblies." The verb used here, hatīś-, have the general meaning of "to give." 30 But in religious contexts, it often means more specifically "to donate," which better fits the context of this inscription. ${ }^{31}$ The inscription does not specify what this $\bar{a} m \bar{a} c a$ official donated, but it is very likely that the thing being donated was the painting on which this inscription was written. The phrase "in love of bodhi" is commonly found in Khotanese donation texts. For instance, when commissioning a text about the Buddha's former births titled Jätakastava, the donor "ordered it to be written in love of bodhi." 32 The phrase "Four Assemblies" refers to the four groups of Buddhists: monks, nuns, laymen, and laywomen. The genitive plural construction "of the Four Assemblies" shows that the donation was not merely for the personal benefit of the donor, but that of all Buddhist devotees.

The title $\bar{a} m \bar{a} c a$ held by the donor of this painting derives from the Sanskrit term āmātya, meaning "minister."33 In eighth century secular documents from Khotan, this term was often used in combination with other titles to denote an official of the highest status in the government of Khotan. ${ }^{34}$ Because of the centrality of this office in the Khotanese bureaucracy, it also appeared in Chinese (as Amozhi) and Tibetan (as A-ma-cha), the languages of the two empires that ruled Khotan between the seventh and ninth centuries. In Khotanese documents from Dunhuang, most of which date to the tenth century, ${ }^{35} \bar{a} m \bar{a} c a$ remained an important office. For instance, in the preface to the Jätakastava mentioned above, the writer prays for the people of Khotan: after mentioning the king, the queen, and the princes, the writer continues to list "the great prime minister (tsai-syām < Ch. Zaixiang), āmāca the servant of the god" as well as "the good, the bad, and the middle, all the people in the country." 36 From the hierarchical sequencing 
of the prayer, it is clear that in the tenth century, $\bar{a} m \bar{a} c a$, while lower than that of the prime ministers, was still one of the most important titles in Khotan. It is therefore fitting that an $\bar{a} m \bar{a} c a$ should have had the means to commission such a lavish silk painting. But how did a painting commissioned by a Khotanese official end up in the library cave in Dunhuang? To answer this question, we need to place the life of this painting in the context of the political history of Eastern Eurasia in the ninth to tenth centuries.

\section{Dunhuang and Khotan: Silk Road Envoys and Buddhist Patronage}

The ninth and tenth centuries were an era of political fragmentation across Eurasia. The three empires, the Tibetan Empire (618-842), the Uyghur Empire (744-840), and the Tang dynasty (618-907) that dominated Eastern Eurasia in the previous centuries all fell in the mid to late-ninth century. ${ }^{37}$ Both Khotan and Dunhuang were under the rule of the Tibetan empire until the mid-ninth century, when both acquired political independence. While it is very likely that Khotan and Dunhuang exchanged envoys in the ninth century, our earliest documentation about such exchange dates to $901 .^{38}$ The diplomatic relation between the two states was further solidified during the tenth century through intermarriage between the Khotanese royal family and the Cao family that ruled Dunhuang ${ }^{39}$ As a result, there was no major warfare between these two states for at least a century, and images of the kings and queens of Khotan decorated the Dunhuang caves next to those of the lords of Dunhuang. ${ }^{40}$ Although about a thousand miles (or $1564 \mathrm{~km}$ on the closest modern highway) apart from each other, Dunhuang and Khotan in the ninth and tenth centuries had a uniquely close relationship.

This close relationship was sustained by a frequent exchange of personnel. Scholars have noticed that a large number of the Khotanese-language documents found in the library cave in Dunhuang are reports by Khotanese envoys. ${ }^{41}$ The Dunhuang government and monasteries often 
provided accommodations for Khotanese envoys and monks. ${ }^{42}$ Similarly, many Dunhuang residents also traveled to Khotan, as is made clear by the many contracts made by these travelers. ${ }^{43}$ As a result, there was likely a constant presence of Khotanese elites, including princes, princesses, governmental officials and Buddhist monks, in Dunhuang in the ninth and tenth centuries. ${ }^{44}$

These Khotanese luminaries engaged with the local society of Dunhuang as Buddhist patrons. Dunhuang was known as a particularly important place for Buddhist activities. In Khotanese texts, Dunhuang is sometimes described as a "land of god (gyastaljasta-kșīra)." Many Khotanese travelers who visited Dunhuang were monks themselves. For instance, according to an envoy's report, a diplomatic mission to China from Khotan led by a certain Ana Saṃgaa had eleven ācārya (Buddhist teachers) and six gṛhastha (householders). ${ }^{46}$ But even laypeople like these householders were likely also Buddhists. Khotanese monks and laypeople alike engaged in Buddhist devotional activities, such as the lighting of lamps, the organization of vegetarian feasts at Buddhist monasteries, the building of stūpas, and the construction of Buddhist caves. For instance, a Khotanese envoy named Șaṃdū "went around the city to 121 shrines," and "sent 502 liters of oil for use in all the temples situated around the city" when he was in Dunhuang. ${ }^{47}$

One of the most important and visible ways Khotan people engaged with the Buddhist communities in Dunhuang was through the making of paintings. A prime minister from Khotan commissioned paintings in Dunhuang caves to pray for good relations between Dunhuang and Khotan and the health of both sovereigns. In this prayer, he described the painting process as "Yielding the precious treasure of exotic nature, I summoned crafty artisans of the red and black colors. [The artisans] drew the ornamentations of tathāgata, and painted the true image of 
bodhisattvas."48 Among the nearly five hundred caves in the Mogao Buddhist complex, several have been identified as either having been repaired or constructed by Khotanese donors. ${ }^{49}$

On the topic of the sponsorship of paintings by Khotanese donors, one letter is particularly relevant to the painted banner under discussion. In 964, a female Khotanese servant residing in Dunhuang wrote a letter to Khotan, in which she asked the princess and prime minister in Khotan to send support for the construction of a cave shrine. Among the things she asked were "colors for painting" (huacaise) and "colored thread for making an embroidered image for the Sanjie monastery (Sanjiesi xiuxiang xianse)." Sanjie monastery" likely refers to items that were donated to the Sanjie monastery. As Rong Xinjiang has shown, the Sanjie monastery was the original repository of many manuscripts and artifacts that were later deposited in the Dunhuang library cave. ${ }^{51}$ The 964 letter provides a concrete example of Khotanese officials donating religious images to the Sanjie monastery. In a similar way, the Mahāmayūrī banner may also have been donated to the Sanjie monastery, after which it was deposited in the library cave. Our $\bar{a} m \bar{a} c a$ official *Yaraișa could have had this painted banner made in Khotan and brought to Dunhuang, or he could have traveled to Dunhuang himself and commissioned the banner there. In either scenario, the distinctive Khotanese style reflects the impact of Khotanese visual culture upon artistic production in Dunhuang.

The Mahāmayūrī banner is not the only painting bearing Khotanese inscriptions that were found in the Dunhuang library cave. There are about half a dozen known examples of paintings on paper and silk with Khotanese inscriptions, and this recent acquisition by the Metropolitan Museum of Art is a spectacular addition to this small but important group of materials. ${ }^{52}$ A few common features unite the Mahāmayūrī banner and these other pieces: First, they were 
commissioned by Khotanese donors, likely officials and other social elites. Second, the objects were either made in Khotan then brought to Dunhuang, or they were made in Dunhuang at the demand of Khotanese donors. Third, these items were likely donated to monasteries in Dunhuang, particularly the Sanjie monastery, as offerings. Because of their similarities, these paintings merit further scholarly attention as a coherent set of materials, which will allow us to have a better understanding of the presence and the role of Khotanese art, and also Khotanese people, in Dunhuang.

\section{The Afterlives of the Mahāmayūrī Banner}

In 2007, the banner was auctioned at Christie's London. ${ }^{53}$ It was part of a sale by the Andrews family, who were stated as owners of the painting through their descent from Frederick Henry Andrews (1866-1957). Fred Andrews had been friend and assistant to the archaeologist, Marc Aurel Stein (1862-1943). During four expeditions to Central Asia, Stein acquired numerous artifacts and Andrews assisted with their cataloguing and study, as discussed further below. If we take as a reasonable starting assumption that this painting came from the library cave, then how did Fred Andrews acquire it? ${ }^{54}$ Did he buy the painting himself, or could it have been given him by Stein?

The former seems implausible. Andrews's financial situation was not robust. ${ }^{55}$ It is unlikely he could have afforded this painting were it offered for sale. Secondly, this piece was in a fragmentary and unconserved condition when it came to Christie's. If Andrews had bought it either for his own pleasure or for, resale, it would be a reasonable assumption that he would have had it mounted and framed — or that it would have been mounted before sale to him — to increase its worth. So, while we cannot say with certainty that Andrews did not buy this piece, it is not a well-supported hypothesis. Is it possible that it was gifted to him by Stein? It was a 
condition of his grants that all finds were to join museum collections in Britain and India and Stein was meticulous in recording his finds in situ, making such gifts unlikely. ${ }^{56}$

If Andrews did not purchase or receive the painting as a gift and it was originally part of Stein's collection, then how might it have found its way to Andrews? As will be argued below, it is plausible that he acquired it accidentally because of the nature of this particular collection. In order to understand this situation, some background on the relationship between Stein and Andrews and of the acquisition and documentation of material from Dunhuang is necessary. Andrews, a graduate of St Martin's School of Art in London, arrived in Lahore in 1890 to become Vice-Principal of Mayo College of Art. There he met Stein, with whom he remained friends to the end of Stein's life. He also worked as an assistant for Stein on the collections. Stein was meticulous about record-keeping and gave most of the artifacts he excavated a unique site mark when in the field, writing it on the artefact itself. He kept lists of these so that, when unpacked, the material could be cross-checked. These lists were also published in his expedition reports. All the material was to be deposited in public collections.

In 1907, Stein visited Dunhuang on his second expedition (1906-8) and acquired thousands of manuscripts and hundreds of textiles and portable paintings on silk, paper and hemp from the library cave. This material was not acquired through excavation but in rushed and clandestine circumstances in which Stein and his assistant, Jiang Xiaowan (d. 1922), were given bundles of material by the unofficial guardian of the cave, Wang Yuanlu to examine secretly. ${ }^{57}$ These items were inscribed with a site mark, such as Ch.i.001, 'Ch.' indicating Dunhuang (Ch'ien-fo'tung), ' $i$ ' the bundle number and '001' the serial number (although it is probable that the serial number was only added later). ${ }^{58}$ 
When preparing for their departure from the field in July 1908, Jiang started to unpack, number, list and repack all regular bundles, making index slips as he went along. ${ }^{59}$ But he only had time to record about one third of the material and, although his index slips were used during the unpacking at the British Museum, they have to date not been located by these authors. Unlike other material, therefore, there was no complete master list to use for checking when unpacking the Dunhuang material in London, nor did they all contain a site mark. ${ }^{60}$

When Stein's finds arrived in England in 1909, Andrews was employed by the India Office Library to unpack, sort and list them. Stein notes in July 1910 that 70-80 banners had been flattened. ${ }^{61}$ Most of the paintings required some basic conservation before they could be identified and catalogued. In many cases, pieces of paper or silk were discovered in scrunchedup balls or stuck together with other pieces, either deliberately —old textiles and paper being used for patching —or accidentally as a result of being squashed together in storage.

Two sections of a catalogue of the paintings were compiled by the French scholar Raphael Petrucci (1872-1917) and published as Appendix E to Stein's expedition report. ${ }^{62}$ Laurence Binyon (1869-1943), Assistant-Keeper in charge of the Sub-Department of Oriental Prints and Manuscripts at the British Museum, and his assistant, Arthur Waley (1889-1966), took over this work after Petrucci's early death. A list of all the identified paintings was prepared for the end of the chapter on Dunhuang, but the banner is not mentioned in this nor in the Appendix.

Stein's second expedition was funded jointly by the India Office and the British Museum, with the agreement that the finds would be divided: three-fifths to go to India and two-fifths to the British Museum. In 1918, the selection of those for India was packed into 67 crates and sent to the India Office in London for safekeeping during the war. ${ }^{63}$ Those for the British Museum were also packed for safe keeping and in 1919 were acquisitioned into the British Museum 
collections. ${ }^{64}$ The others were shipped to India. ${ }^{65}$ The banner was not listed as among any of these either.

However, this does not mean it was not from Stein's second expedition. By no means had all of the material been conserved at this time and some remained in a state which conservators of the time did not feel able to tackle. Many of the original bundles are marked as having being returned from conservation in these early years as untreatable. ${ }^{66}$ So, it is possible that the painting was among the second expedition material kept at the British Museum in an unidentified state. Furthermore, material from Stein's third expedition (1916-18) was sent to British India to be conserved, listed, and prepared for acquisition. Stein had acquired more material from Dunhuang on this expedition and while there is no evidence of paintings or banners among them, it is not impossible that some of the material included unconserved fragments such as the banner. ${ }^{67}$

It is certain that this painting is not described in Stein's published reports, nor in any of the unpublished lists and correspondence. This strongly suggests that it was not recognized at this time. This could be because it was either pasted on to the back of another painting or sandwiched between outer wrappers or remaining in a squashed bundle. It is also not impossible that it was among material that Andrews had at home. For a scholar to work on material at home was quite usual at this time, and items from the Stein collections were often sent to specialists in London and further afield. Andrews certainly worked on material at home, as is shown by later correspondence from Stein asking him to look for certain items.

Could such an item have remained with Andrews and only later been unfolded to be revealed as an important painting? It is not farfetched to suggest that Andrews, with his background, familiarity with the material and knowledge of the conservation work, did this 
himself. But then if he discovered this piece in such a way some time after the expeditions, why did he not inform Stein about it and ensure that it was returned to the collection? Or was it only discovered after Stein's death? But then Andrews might have been expected to return it to the museum. ${ }^{68}$

We cannot at present — and might never — be able to answer these questions. But it remains most probable that the banner was from the library cave at Dunhuang, acquired by Stein either in 1907 or during 1913-16 but then in a condition unrecognizable as a fine painting. It is possible that—still unrecognized — it accidentally remained in Andrews' possession and only came to light after Stein's death in 1943, and that Andrews either forgot about it or died before it could be unfolded. The subsequent arrival of the banner at the Metropolitan Museum of Art thus closes the circle on the intriguing journey of this important painted silk banner, from its initial production, its circulation within the cultural milieu of medieval silk road oasis cities, and finally, its acquisition in the early twentieth century to the present-day.

\section{Acknowledgments}

We gratefully acknowledge assistance and support from Kurt Behrendt, Minsun Hwang, Joseph Scheier-Dolberg, Pengliang Lu, and Niv Allon at the Metropolitan Museum of Art; Yu-ping Luk at the British Museum; Yoojin Choi and Ricarda Brosch at the Victoria and Albert Museum; Mélodie Doumy and Sam van Schaik at the British Library; and Allan Ding, Erika Forte, Amy Gansell, Ciro Lo Muzio, Megan Martinsen, Miki Morita, Wang Le, and Stuart Young.

\footnotetext{
${ }^{1}$ T982, T984, T985, T986, T987, T988. The various recensions bear slightly different titles but share in common a focus on Mahāmayūrī and the healing or apotropaic properties of his incantation (dhāraṇī or mantra).

${ }^{2}$ These are the translations by Śrīmitra (T986, T987) and Kumārajīva (T988). For studies of the Mahāmayūrī dhāraṇī sūtra, see Sørensen 2006, Des Jardins 2011, and Overbey 2016.

${ }^{3}$ T19.987.479a29-b3.

${ }^{4} \mathrm{~T} 19.987 .479 \mathrm{~b} 3-9$

${ }^{5}$ T19.987.479b9-11; T19.988.483a27-29. This narrative framework appears in T987 and in the Kumārajīva translation (T988).
} 
${ }^{6}$ For example, a medicine bowl is one of the objects commonly wielded by the medicine Buddha Bhaisajyaguru in paintings and sculptures.

${ }^{7}$ Pandey and Pandey 1988, pp. 9-10.

${ }^{8}$ According to the ritual manual attributed to Amoghavajra, Ritual Commentary Spoken by the Buddha on the Altar of the Great Peacock Wisdom King's Image (Foshuo Da kongque mingwang huaxiang tanchang yigui; T983A), the four-armed Mahāmayūrī is seated on a "golden peacock king" and holds peacock feathers in his second left hand; see T19.983A:440a4-10. Although Mahāmayūrī is represented in the Metropolitan Museum banner as a two-armed standing deity, the association with the peacock and peacock feathers remains consistent.

${ }^{9} \mathrm{~T} 19.986 .477 \mathrm{c} 7-8$.

${ }^{10}$ Mahāmayūrī was also associated with rain-making rituals and with Buddhist kingship. For images of Mahāmayūrī in Dunhuang and Sichuan, see Wang 1996, Hashimura 2011, and Wang forthcoming.

${ }^{11}$ See Copp 2014.

${ }^{12}$ Wang 2007, pp. 58-59. For hemp banners from Dunhuang, see Whitfield 1998.

${ }^{13}$ On non-human agency in Buddhist rituals, see Wang 2011 and Kim 2017.

${ }^{14}$ For a relevant passage from the Sütra of the Revered and Victorious Dhäraṇi of the Buddha's Uṣnịșa, see Copp 2014, p. 146.

${ }^{15}$ Based on her reinterpretation of the mural painting on the south wall of Mogao Cave 217, Shimono Akiko argues that visual evidence exists for the practice of inscribing dhäranis upon a cloth banner, and then hanging the banner from a tall structure; see Shimono 2004. For an important recent treatment of dhāran̄i pillars, see Liu 2008, in which the author argues for the multivalent associations of dhäraṇi pillars, stating that they functioned not only as vehicles for dhäranīis but also as stūpas.

${ }^{16}$ Huang and Wu 1995, p. 159. Thanks to Allan Ding for this reference.

${ }^{17}$ The double-sided Turfan banners are also discussed in Zaleski 2016, p. 83. Thanks to Mélodie Doumy for this reference.

${ }^{18}$ This technique is discussed in Zaleski 2016, p. 85.

${ }^{19}$ See Zhao 2007b, pp. 192-195.

${ }^{20}$ Double-faced weave silk fabrics are known from the silk routes, resulting in different colors and even different patterns on each side of the fabric. For an example, see Zhao 2007a, plate 124.

${ }^{21}$ For the archaeological report, consult Stein 1921, Volume 2, pp. 1073-1075.

${ }^{22}$ There are two Tibetan inscriptions on the verso, one of which is a rough transliteration of the deity's name ( $b a c a$ ra pang ne). For the inscription, see Whitfield and Williams 2004, p. 210, plate 131.

${ }^{23}$ For the British Museum paintings, see Whitfield 1982-1985, Volume 1, pp. 333-334. For the National Museum of India paintings, see Chandra and Sharma 2012, pp. 221-223.

${ }^{24}$ Compare, for example, to the solid-colored textiles in "Banner with Avalokiteśvara," Tang dynasty (618-907) or Guiyijun period (848-1036), ink and color on silk, 56.5 x $16.5 \mathrm{~cm}$., British Museum, 1919,0101,0.124 (Ch.00113). Because of the striped textiles of the garments and the ill-defined musculature of the bodhisattvas, which are also present in mural paintings from Balawaste, located in the eastern part of the Khotan oasis in present-day Xinjiang Uygur Autonomous Region, Gerd Gropp has argued that they are Khotanese in origin; see Gropp 1974, p. 94.

${ }^{25}$ In the premodern connoisseurial literature, Khotanese painters such as Yuchi (Weichi) 尉迟 Yiseng 乙僧 (active second half of the seventh century) were known for their technique of chiaroscuro. For a synthesis of the relevant primary sources on Khotanese painters, see Nagahiro 1955, p. 73.

${ }^{26}$ Khotanese painting is said to reflect South Asian, Chinese, Sasanian, and Sogdian elements. See Williams 1973, pp. 110-111. It is worth noting that the unusual standing position of Mahāmayūrī, who is usually shown seated on a peacock mount, echoes sixth century Mahāmayūrī sculptures at Ellora in western India; see Malandra 1993, pp. 9697. Malandra notes that Mahāmayūrī is paired with Bhṛkuṭị in Ellora Caves 6 and 8, which is unique to the site, and that there are no textual precedents for Mahāmayūrī’s appearance. Nevertheless, the standing posture is very common in representations of deities in painted banners, so this does not imply a direct connection but rather points toward two distinct treatments of the standing Mahāmayūrī.

${ }^{27}$ This way of writing Khotanese inscription on paintings is more common than when the writer writes the inscriptions vertically along the vertical direction of the painting, which is found in P.t.2222 in the Bibliothèque nationale de France. See Filigenzi and Maggi 2008.

${ }^{28}$ This name is not otherwise attested in Khotanese texts.

${ }^{29}$ For a similar inscription that begins with the date, see Stein 1921, vol. 2, p. 1012.

${ }^{30}$ Emmerick 1968, p. 145.

${ }^{31}$ See the examples in Bailey 1979, pp. 448-9. 
${ }^{32}$ Skjærvø 2002, p. 299.

${ }^{33}$ Olivelle 2013, p. 40. This is the title of the famous minister Yaśa for King Aśoka in the Khotanese legend of Aśoka. See Bailey 1951, pp. 40-4.

${ }^{34}$ Wen 2008, p. 124.

${ }^{35}$ For this dating of the Khotanese documents, see Zhang and Rong 2008, 70-105.

${ }^{36}$ Dresden 1955, p. 422.

${ }^{37}$ For this history, see Chavannes 1942, Maeda 1964, Beckwith 1993, and Drompp 2005.

${ }^{38}$ Rong and Zhu 2013, p. 110.

${ }^{39}$ Rong and Zhu 2013, pp. 151-70.

${ }^{40}$ This is particular true in Cave 98, which contains the largest donor image in all of Dunhuang caves, that of the Khotanese king.

${ }^{41}$ Kumamoto 1982. These envoys also left records in Chinese and Tibetan, in official letters, royal edicts, and notebooks. See Zhang and Rong 2008, pp. 1-14. For the Tibetan documents in particular, see Rong and Zhu 2013, pp. 375-412.

${ }^{42}$ For examples, for Dunhuang government's provision of food to Khotanese envoys see S.1366 in Tang and Lu 1986-1990, vol.3, p. 285; for a Dunhuang monastery's provision of food to Khotanese envoys, see P.2642 in Tang and Lu 1986-1990, vol. 3, p. 209.

${ }^{43}$ In a tantalizing piece of evidence, of the 46 people living in Suo Liuzhu Lane in Dunhuang who were late in their payment of taxation in firewood, twelve were recorded as having traveled to Khotan. See Дx2149 in Tang and Lu 1986-1990, vol. 2, p. 446.

${ }^{44}$ Kumamoto 1996.

${ }^{45}$ IOL Khot S. 21. Skjærvø 2002, pp. 522-4.

${ }^{46}$ P.2958. Bailey 1967, pp. 96-7.

${ }^{47}$ Bailey 1951, p. 44.

${ }^{48}$ P.2812. The Chinese text reads 捨異類之珍財。召丹青之巧匠。繪如來之鋪席, 圖菩薩之真儀. See Zhang and Rong 2008, pp. 91-2.

${ }^{49}$ Chen 2014, pp. 244-7.

${ }^{50}$ Дх.2148(2)+ Дх.6069(1). See Zhang and Rong 2008, p. 293.

${ }^{51}$ Rong 1999-2000.

${ }^{52}$ For these inscribed paintings, see Stein 1921, vol. 2 p. 1012, Emmerick and Dudbridge 1978, Emmerick 1984, Filigenzi and Maggi 2008.

${ }^{53}$ Christie's Sale, 15 May 2007, lot number 0171. https://www.christies.com/lotfinder/lot/an-extremely-rare-andimportant-tang-dynasty-4905708-details.aspx?from=salesummery\&intObjectID $=4905708 \&$ sid=a341 ca $1 \mathrm{a}-466 \mathrm{f}-$ 459f-95dc-95c674287c3a. See http://idp.bl.uk/archives/news_current/news_current.a4d\#section5 for an initial account. (last accessed September 29, 2019)

${ }^{54}$ Although forgeries were produced later of such material, the fragmentary state of this piece, its distinctive subject matter and its sophistication all strongly suggest that this is not a forgery. See Cohen 2002, pp. 24-30 and Whitfield 2002, pp. 96-102 for discussions.

${ }^{55}$ At least this is the impression from reading Stein on Andrews, along with Andrews's dissatisfaction with most of his positions, although Andrews left a reasonable legacy.

${ }^{56}$ The British Museum Act of 1767 allowed the Trustees "to exchange, sell or dispose of any Duplicates of Printed Books....". This was most probably behind the decision to exchange a Dunhuang blockprint from the Stein Dunhuang collection, 1919,0101,0.241 (Ch.00185.a), with an item from the Royal Ontario Museum in 1924 (927.24).

${ }^{57}$ Stein 1921, pp. $801 \mathrm{ff}$.

${ }^{58}$ In the expedition report Stein says "I may note here that when the marking with serial numbers was made at the British Museum ..." (1921, p. 814 n.2).

${ }^{59}$ Although most of the paintings seem to have been listed at this time.

${ }^{60} \mathrm{It}$ is regrettable that the site mark, when given, was not always recorded in catalogues and databases of the material. IDP started recording this information on its database at the British Library but the work is still to be completed. However, from the work done, we can see that the site mark carries important information about the original storage of the manuscripts in the bundles in the cave, as suggested previously by Rong Xinjiang and others. These results will be published in a forthcoming article by Paschalia Terzi and Susan Whitfield.

${ }^{61}$ MSS. Stein 7/81-2. Aurel Stein to Percy Allen. Note that the material was not yet acquisitioned into any collection.

${ }^{62}$ Stein 1921, pp. 1392-1428, following by a short essay by Binyon (pp. 1428-1431). 
63 An exception was made for the Kharoșthī tablets, many due for India but which were still being catalogued. Permission was made for these to be kept unpacked at the British Museum so that the cataloguing could be completed.

${ }^{64}$ Hence the prefix to their museum reg. number, 1919.

${ }^{65}$ Now in the National Museum, New Delhi.

${ }^{66}$ For an example of the state of much of the material before conservation and the time-consuming work in flattening folded material, see the time-lapse video: https://www.youtube.com/watch?v=FIP3jMfZkY4

${ }^{67}$ They included manuscript scrolls and clay relief plaques acquired directly from Wang Yuanlu at the caves, as well as other rolls offered by sellers to Stein in the town and in other places en route. See Stein 1928, pp. 354-62 for a review of these. As Stein notes, this material was in good condition - indeed, Fujieda Akira suggested much of it consisted of forgeries (Fujieda 2002). But, more pertinent to the discussion here, it was not in a form that suggests a painting on silk could be hidden among it.

${ }^{68}$ It is, of course, also possible that it was discovered and unfolded after Andrews death by his family. On his death in 1957, apart from small bequests, his estate passed to his nephew, Richard Cuthbert Andrews, and his wife, Barbara.

\section{REFERENCES}

\section{Primary Sources}

Amoghavajra (Bukong Jin'gang 不空金剛, 705-774), trans.

Fomu da kongque mingwang jing 佛母大孔雀明王經 (Sūtra on the Buddha's Mother, the Great Peacock Wisdom King. T19.982.

Amoghavajra (Bukong Jin'gang 不空金剛, 705-774)

Foshuo da kongque mingwang huaxiang tanchang yigui 佛說大孔雀明王畫像壇場儀軌 (The Ritual Commentary Spoken by the Buddha on the Altar of the Great Peacock Wisdom King's Image). T19.983A.

Bailey, H. W.

Khotanese Buddhist Texts. London: Taylor's Foreign Press, 1951.

Guo Shengbo 郭聲波, ed.

Song huiyao jigao: Fanyi Dao-Shi 宋會要輯稿: 蕃夷道釋 (Collected Documents of the Song Dynasty: Barbarians, Daoists and Buddhists). Chengdu: Sichuan daxue chubanshe, 2010.

Kumārajīva (Jiumoluoshi 鳩摩羅什, 344-413), trans.

Kongquewang zhou jing 孔雀王呪經 (Sütra of the Peacock King Mantra). T19.988.

The Papers of Sir Marc Aurel Stein (1862-1943). Bodleian Library. Oxford. MSS. Stein.

Papers Relating to Sir Marc Aurel Stein. Central Archives, British Museum, London. CE32/23 and CE32/24.

Sanghabhara (460-524), trans.

Kongquewang zhou jing 孔雀王呪經 (Sütra of the Peacock King Mantra). T19.984. 
Skjærvø, Prods O.

Khotanese Manuscripts from Chinese Turkestan in the British Library: A Complete Catalogue with Texts and Translations. Corpus Inscriptionum Iranicarum; Pt. 2, v. 5, Texts 6. London:

British Library, 2002.

Śrīmitra (Boshilimiduoluo 帛尸梨蜜多羅, d. mid-fourth century), trans.

Da jinse kongquewang zhou jing 大金色孔雀王呪經 (Sütra of the Great Golden Peacock King Mantra). T19.986.

Śrīmitra (Boshilimiduoluo 帛尸梨蜜多羅, d. mid-fourth century), trans.

Foshuo da jinse kongquewang zhou jing 佛說大金色孔雀王呪經 (Sütra Preached by the

Buddha on the Great Golden Peacock King Mantra). T19.987.

Tang Geng'ou 唐耕耦 and Lu Hongji 陸鴻基

Dunhuang shehui jingji wenxian zhenji shilu 敦煌社會經濟文獻真跡釋錄 (Transcription and Intepretation of Social and Economic Documents from Dunhuang), 5 vols. Beijing: Shumu wenxian chubanshe, 1986-1990.

Yijing 義淨 (635-713), trans.

Foshuo da kongque zhou wang jing 佛說大孔雀呪王經 (Sütra Preached by the Buddha on the Great Peacock, the King of Mantras). T19.985.

\section{Secondary Sources}

Andrews, Fred $\mathrm{H}$.

1948 Wall Paintings From Ancient Shrines in Central Asia. London: Oxford University Press.

Bailey, H. W.

1951 “The Staël-Holstein Miscellany.” Asia Major new series 2, pp. 1-45.

1967 “Altun Khan.” Bulletin of the School of Oriental and African Studies 30.1, pp. 95104.

1979 Dictionary of Khotan Saka. Cambridge: Cambridge University Press.

Beckwith, Christopher I.

1993 The Tibetan Empire in Central Asia: A History of the Struggle for Great Power among Tibetans, Turks, Arabs, and Chinese during the Early Middle Ages. Princeton, NJ: Princeton University Press.

Bhattacharya-Haesner, Chayya

2003 Central Asian Temple Banners in the Turfan Collection of the Museum für Indische Kunst, Berlin: Painted Textiles from the Northern Silk Route. Berlin: Reimer.

Chandra, Lokesh and Nirmala Sharma

2012 Buddhist Paintings of Tun-Huang in the National Museum, New Delhi. New Delhi: 
Niyogi Books.

Chavannes, Édouard

1942 Documents sur les Tou-Kiue (Turcs) occidentaux, Recueillis et commentés, suivi de notes additionnelles. Paris: Adrien-Maisonneuve.

Chen Suyu 陳粟裕

2014 Cong Yutian dao Dunhuang: yi Tang Song shiqi tuxiang de dongchuan wei zhongxin 從于闐到敦煌：以唐宋時期圖像的東傳為中心 (From Khotan to Dunhuang: Focusing on the Eastern Dissemination of Images in the Tang and Song periods). Beijing: Fangzhi chubanshe.

Cohen, Monique 2002 “Genuine or Fake?” In Dunhuang Manuscript Forgeries, edited by Susan Whitfield, pp. 22-32. London: The British Library.

Copp. Paul F.

2014 The Body Incantatory: Spells and the Ritual Imagination in Medieval Chinese Buddhism. New York: Columbia University Press.

Des Jardins, J.F. Marc

2011 Le sūtra de la Mahāmāyūrī: rituel et politique dans la Chine de Tang (618-907). Quebec City: Presses de l'Université Laval.

Dresden, Mark

1955 "Jātakastava or 'Praise of the Buddha's Former Births'." Transactions of the American Philosophical Society NS 45.5, pp. 397-508.

Drompp, Michael Robert

2005 Tang China and the Collapse of the Uighur Empire: A Documentary History, Brill's Inner Asian Library; v. 13. Leiden; Boston: Brill.

Emmerick, R. E.

1968 Saka Grammatical Studies. London: Oxford University Press.

1984 "Cā tteya khi in the Museé Guimet." Studia Iranica 13.2, pp. 251-2 + pl.xvi.

Emmerick R. E. and Glen Dudbridge

1978 “Pelliot tibétain 0821." Studia Iranica 7.2, pp. 283-5, pl. xv.

Fenet, Annick, Helen Wang, and Susan Whitfield, eds. 2020 La correspondance francophone d'Aurel Stein / The Aurel Stein French-speaking correspondence. Paris: Hermann.

Filigenzi, Anna and Mauro Maggi

2008 "Pelliot tibétain 2222: a Dunhuang Painting with a Khotanese Inscription." Journal of Inner Asian Art and Archaeology 3, pp. 83-9. 
Forte, Erika

2014 "On a Wall Painting from Toplukdong Site No. 1 in Domoko: New Evidence of Vaiśravaṇa in Khotan?" In Changing Forms and Cultural Identity: Religious and Secular Iconographies. Vol. 1, Papers from the 20th conference of the European Association for South Asian Archaeology and Art held in Vienna from 4th to 9th of July 2010, edited by Deborah Klimburg-Salter and Linda Lojda, pp. 215-224, 243. Turnhout: Brepols Publishers.

Fujieda Akira

2002 "Chronological Classification of Dunhuang Buddhist Manuscripts." In Dunhuang Manuscript Forgeries, edited by Susan Whitfield, pp. 103-114. London: The British Library.

Gropp, Gerd

1974 Archäologische Funde aus Khotan Chinesisch-Ostturkestan: die TrinklerSammlung im Übersee-Museum, Bremen. Bremen: Röver.

Hashimura Aiko 橋村爱子

2011 “Tonkō Bakkōkutsu oyobi Anzai Yurinkutsu no Kujaku myōō (Mahāmayūrī) ni tsuite - Kigigun setsudoshi Sōshi ni yoru mikkyō juyō no ichi danmen 敦煌莫高窟及び 安西榆林窟の孔雀明王 (Mahāmayūrī)について - 帰義軍節度使曹氏による密教受容 の一断面” (Regarding Mahāmayūrī in the Mogao and Yulin Caves - One Section of Esoteric Buddhist Content under the Cao Clan of the Guiyijun Military Commanders). Nagoya daigaku daigakuin bungaku kenkyūka bigaku bijutsushi kenkyūshitsu 名古屋大 学大学院文学研究科美学美術史研究室 25, pp. 27-54.

Huang Zheng 黄徵 and Wu Wei 吴偉, eds.

1995 Dunhuang yuanwenji 敦煌願文集 (Collected Dunhuang Prayer Texts). Changsha: Yuelu shushe.

Kim, Youn-mi

2017 "Buddhist Ontology and Miniaturization: Enacting Ritual with Nonhuman Agency." International Journal of Buddhist Thought and Culture 27, no. 2, pp. 39-69.

Kumamoto Hiroshi 熊本裕

1982 "Khotanese Official Documents in the Tenth Century A.D." PhD diss., University of Pennsylvania.

1996 "The Khotanese in Dunhuang." in Cina e Iran de Alessandro Magno alla dinastia

Tang, edited by A. Cadonna and L. Lanciotte. Florence: Leo S. Olschki Editore, pp. 79101.

Liu Shufen 劉淑芬

2008 Miezui yu duwang: Foding zunsheng tuoluoni jingchuang zhi yanjiu 滅罪與度亡: 佛頂尊勝陀羅尼經幢之研究 (Expiating Sins and Death: Study of Uṣn̄ịsavijayā Dhāraṇī Page 24 of 27 
Pillars). Shanghai: Shanghai guji chubanshe.

Maeda Masana 前田正名

1964 Kasei no rekishi-chirigakuteki kenkyū 河西の歴史地理学的研究 (A Study of the Historical Geography of the Hexi Region). Tōkyō: Yoshikawa Kōbunkan.

Malandra, Geri H.

1993 Unfolding a Mandala: The Buddhist Cave Temples at Ellora. Albany, NY: State University of New York Press.

Mirsky, Jeanette

1998 Sir Aurel Stein: Archaeological Explorer. Chicago and London: University of Chicago Press.

Morita, Miki

2015 "The Kizil Paintings in the Metropolitan Museum." Metropolitan Museum Journal 20, pp.115-132.

Nagahiro, Toshio

1955 “On Wei-ch'ih I-seng: A Painter of the Early T'ang Dynasty.” Oriental Art 1, no. 2, pp. 70-74.

Olivelle, Patrick

2013 King, Governance, and Law in Ancient India: Kautilya's Arthasastra. New York:

Oxford University Press.

O’Neale, Lila M. and Dorothy F. Durrell

1945 "An Analysis of the Central Asian Silks Excavated by Sir Aurel Stein."

Southwestern Journal of Anthropology 1, no. 3, pp. 392-446.

Overbey, Ryan Richard

2016. "Vicissitudes of Text and Rite in the Great Peahen Queen of Spells." In Tantric

Traditions in Transmission and Translation, edited by David B. Gray and Ryan Richard Overbey, pp. 257-283. New York, NY: Oxford University Press.

Pandey, V.N. and Ayodhya Pandey

1988 "A Study of the Nāvanītaka: The Bower Manuscript." Bulletin of the Indian

Institute of History of Medicine 18, pp. 1-46.

Rong Xinjiang

1999-2000 "The Nature of the Dunhuang Library Cave and the Reasons of Its Sealing." Cahiers d'Extreme-Asie 11, pp. 247-75.

2007 "Ye Changchi: Pioneer of Dunhuang Studies.” IDP News 7, pp. 2-3.

Rong Xinjiang 榮新江 and Zhu Lishuang 朱麗隻

2013 Yutian yu Dunhuang 于闐與敦煌 (Khotan and Dunhuang). Lanzhou: Gansu jiaoyu chubanshe. 
Shimono Akiko 下野玲子

2004 “Tonkō Bakukōkutsu dai 217 kutsu nanheki kyōhen no shin kaishaku” 敦煌莫高窟 第二一七窟南壁經變の新解釋 (A New Interpretation of the Painting on the South Wall of Mogao Cave 217 at Dunhuang). Bijutsushi 美術史 54, no. 1, pp. 96-115.

Sørensen Henrik H.

2006 "The Spell of the Great, Golden Peacock Queen: The Origin, Practices, and Lore of an Early Esoteric Buddhist Tradition in China." Pacific World third series 8, pp. 89-123.

Stein, Marc Aurel

1907 Ancient Khotan. Oxford: The Clarendon Press.

1921 Serindia: Detailed Report of Explorations in Central Asia and Westernmost China, 5 vols. Oxford: Clarendon Press.

1928 Innermost Asia. Oxford: The Clarendon Press.

Wang, Eugene

2011 "Ritual Practice without Its Practitioner?: Early Eleventh Century Dhāraṇī Prints in the Ruiguangsi Pagoda." Cahiers d'Extrême-Asie 20, pp. 127-162

Wang, Helen

1998 "Stein's Recording Angel - Miss F. M. G. Lorimer." Journal of the Royal Asiatic

Society 8, no. 2, pp. 207-228. doi:10.1017/S1356186300009986

Wang Huimin 王惠民

1996 “Lun «Kongque mingwang jing» jiqi zai Dunhuang, Dazude liuchuan 论《孔雀明王 经»及其在敦煌大足的流传” (Discussing the Mahāmayūrī Sūtra and its Circulation in Dunhuang and Sichuan). Dunhuang yanjiu 敦煌研究 1996.4, pp. 37-47.

Wang Le

2007 "Banners." In Textiles from Dunhuang in UK Collections, edited by Zhao Feng, pp. 58-91. Shanghai: Donghua University Press.

Wang, Michelle C.

Forthcoming "Birds of a Feather: Mahāmayūrī between Khotan and Dunhuang." From the Book to the Silk Road(s), edited by Michelle C. Wang and Ryan Richard Overbey.

Wen Xin 文欣

2008 “Yutian guo guanhao kao" 于闐國官號考 (A Study on Official Titles in the Kingdom of Khotan). Dunhuang Tulufan yanjiu 敦煌吐魯番研究 (Dunhuang and Turfan Studies) 11, pp. 121-46.

Whitfield, Roderick

1982-1985 Art of Central Asia: The Stein Collection in the British Museum, 3 vols. Tokyo: Kodansha International, in cooperation with the Trustees of the British Museum. 
1998 "Four Unpublished Paintings from Dunhuang in the Oriental Collections of the British Library." The British Library Journal 24, no. 1, pp. 90-97.

2002 "Forgeries and Dunhuang Paintings." In Dunhuang Manuscript Forgeries, edited by Susan Whitfield, pp. 96-102. London: The British Library.

Whitfield, Susan, ed.

2002 Dunhuang Manuscript Forgeries. London: The British Library.

Whitfield, Susan and Ursula Sims Williams, eds.

2004 The Silk Road: Trade, Travel, War, and Faith. London: British Library.

Williams, Joanna

1973 “The Iconography of Khotanese Painting.” East and West 23, nos. 1-2, pp. 109-154.

Yetts, W. Perceval

1924 "Messrs. Yamanaka and Co." Burlington Magazine for Connoisseurs 45.261, pp. 315-316.

Zaleski, Valerie

2016 "On a Silk Banner in the Musée Guimet: A Chinese Contribution to the Service of Buddhist Devotion in the Oasis of Dunhuang." Orientations 47, no. 4, pp. 82-88.

Zhang Guangda 張廣達 and Rong Xinjiang 榮新江

2008 Yutianshi congkao 于闐史叢考 (Collected Essays on the History of Khotan). 2nd ed. Beijing: Zhongguo renmin daxue chubanshe.

Zhao Feng

2007a Textiles from Dunhuang in UK Collections, edited by Zhao Feng. Shanghai: Donghua University Press.

2007b "Clamp-resist dyed silk." In Textiles from Dunhuang in UK Collections, edited By Zhao Feng, 192-213. Shanghai: Donghua University Press. 